\title{
Effect of different mulching materials on weeds and yield of Chili cultivars
}

\author{
Muhammad Noman Khan ${ }^{1}$, Gohar Ayub ${ }^{1}$, Mohammad Ilyas ${ }^{1}$, Maaz \\ Khan ${ }^{1}$, Faheem Ul Haq ${ }^{1}$, Jawad $\mathrm{Ali}^{2 *}$ and Aftab Alam ${ }^{3}$ \\ 1. Department of Horticulture, The University of Agriculture Peshawar - Pakistan \\ 2. Department of Agriculture, University of Swabi, Anbar-Pakistan \\ 3. Department of Soil and Environmental Sciences,The University of Agriculture Peshawar-Pakistan \\ *Corresponding author's email: jwd.ali88@ gmail.com \\ Citation \\ Muhammad Noman Khan,Gohar Ayub, Mohammad Ilyas, Maaz Khan, Faheem Ul Haq,Jawad Ali and Aftab Alam. \\ Effect of different mulching materials on weeds and yield of Chili cultivars. Pure and Applied Biology. Vol. 5, \\ Issue 4, pp1160-1170. http://dx.doi.org/10.19045/bspab.2016.50139
}

\begin{tabular}{llll}
\hline \hline Received: 03/09/2016 & Revised: 29/09/2016 & Accepted: 14/10/2016 & Online First: 28/10/2016 \\
\hline
\end{tabular}

\section{Abstract}

To evaluate the effect of different mulching materials on the weeds and yield of chili cultivars, an experiment was conducted at Horticulture Research Farm at University of Agriculture, Peshawar, during the year 2014. The experiment was carried out in Randomized Complete Block Design (RCBD) with three replication.. There were two factors i.e. mulching materials (Wheat straw, Saw dust, Transparent plastic, Black plastic, Unmulched) and chili cultivars (PusaJawala, Sky Star, Hot Green, Green Star).Minimum weed density $\mathrm{m}^{-2}$ (19), maximum yield tons ha ${ }^{-1}$ (3.07) were found when black plastic was used, while maximum weed density $\mathrm{m}^{-2}$ (209), were found, when transparent plastic was used. Highest soil moisture content (\%) was found under black and transparent plastic mulch. Wheat straw and saw dust also increase growth and yield components of chili as compare to Unmulched plots. Lowest soil moisture content $(16.1 \%)$ and minimum yield tons $\mathrm{ha}^{-1}(0.70)$ were recorded from Unmulched plots. In case of cultivars maximum yield tons $\mathrm{ha}^{-1}$ (2.33) were noted in cultivar Sky Star. It is concluded from the results that cultivar Sky star along with black plastic mulch proved better with respect to weed control and yield and should be used for higher production of chili under the agro climatic conditions of Peshawar.

Keywords: Chili, Soil moisture (\%), Number of Fruits, Fruit length, Fruit weight

\section{Introduction}

Chili (Capsicum annuum L.) plant botanically referred to genus Capsicum and belong to family Solanaceae. chilli ranks ranks third [1]. Chilies can be grown in both tropical and sub-tropical climate regions where danger of frost is very little. Temperature requirement of chili is $20-25$ ${ }^{\circ} \mathrm{C}$. It is native to the Tropical South America and Brazil [2]. Chili is one of the key economic vegetable cultivated in
Pakistan and is used as a salad and also as dried condiments. Two of its varieties are mainly cultivated in Pakistan which is Capsicum annum and Capsicum frutescens [3]. Chilies are good sources of vitamin A and $\mathrm{C}$, and also contain considerable amount of calcium, phosphorus and iron.Capsacin is responsible for pungency [3]. India ranks first in chili production which is followed by China-Pakistan also produces and export chili but as compare to other countries of the 
world it is quite low. In Pakistan, chili is cultivated on 73.8 thousand hectares with total production of 187.7 thousand tones and average yield of 2.5 tons $\mathrm{ha}^{-1}$. In Khyber Pakhtunkhwa (KPK) it is grown on 0.6 thousand hectares with total production of 0.7 thousand tones while its average yield is 1.2 tons ha-1 [4].

Mulching is the practice of covering the soil surface to make it more suitable for plant growth, development and good crop production [5]. Mulches are either organic or inorganic. The organic mulch include plant remains such as straw, hay, peanut hulls, leaf mold and compost, wood products such as sawdust, wood chips and animal manures while inorganic mulch includes plastic mulch which is the most important mulch material use in commercial crop production [6]. It has been noted that organic and inorganic mulches play important role in vegetable production especially under rain fed situations. Mulches not only conserve soil moisture but along with modification of soil temperature also check the weed density, which ultimately increase the total and early yield. In subtropical climate, the pepper exhibited rapid growth when grown on transparent polyethylene film as compared to other organic mulches [7] while in semi-arid climate black plastic mulch showed injurious effects as it blistered the fruits which result in decreased yield [8].

Production of vegetables and other crops in semi-arid areas is hindered by the scarcity of water, the major part of the growing season usually being characterized by the low rainfall and high evapotranspiration rates [9]. Chili is sensitive to water stress, young chili seedlings cannot withstand earlier water stress while older plants can withstand deflects or excess of soil moisture [10]. It is investigated that polyethylene mulches (transparent and black) are completely resistant to water and therefore reduces immediate loss of water from the soil surface and decreases the moisture losses and conserve soil particles over the surfaces [11]. In this way mulching plays important role in water conservation for extended period of time but it also accelerates soil temperature as well [12]. After transplantation pepper seedlings are very sensitive to weed infestation that's why weeds infestation is known as one of the serious problem in pepper production. [13]. Polyethylene mulches significantly contributed to reduction of losses due to weeds [14].

In Pakistan chili production is quite low mainly in KPK, as compare to other countries of the world. There are many reasons which are responsible for its low production like poor culture practices, poor selection of cultivars and no use modern of technologies. In Pakistan chili is mainly grown in summer months which greatly suffer from water stress and weed infestation, farmers of Pakistan are also unaware of the use of mulching materials.

Keeping in view the importance of proper cultivar, soil moisture conservation, weed control and modification of soil temperature an investigation was undertaken to study the effect of different mulching materials on the growth and yield of chili cultivars at Horticulture Research Farm of the University of Agriculture Peshawar with the objectives to investigate the effect of different mulching materials on growth and yield of chili cultivars and to sought out a suitable mulching material for maximum growth and yield of chili.

\section{Materials and methods}

The experiment "Effect of different mulching materials on the growth and yield of chili cultivars" was conducted at Horticulture Research Farm, the University of Agriculture, Peshawar, during 2014.

\section{Soil analysis}


Soil samples were collected randomly from the experimental plot using Auger from a depth of $10 \mathrm{~cm}$ before sowing and after harvest. The chemical analysis of soil samples was done in soil laboratory, the University of Agriculture Peshawar. Soil analysis was shown in (Table 1 and 2).

Table 1. Soil analysis before Sowing

\begin{tabular}{|l|c|}
\hline Soil characteristics & Value \\
\hline $\mathrm{pH}$ & 7.2 \\
\hline $\mathrm{EC}\left(\mathrm{ds} \mathrm{m}^{-1}\right)$ & 0.32 \\
\hline $\mathrm{OM}(\%)$ & 1.2 \\
\hline
\end{tabular}

Table 2. Soil analysis after harvesting

\begin{tabular}{|c|c|c|c|}
\hline Treatments & pH & $\mathrm{EC}\left(\mathrm{dS} \mathrm{m}^{-1}\right)$ & OM (\%) \\
\hline Unmulched & 7.2 & 0.32 & 1.1 \\
\hline Wheat straw & 7.1 & 0.26 & 1.38 \\
\hline Saw dust & 6.8 & 0.25 & 1.40 \\
\hline Transparent plastic & 7.0 & 0.31 & 1.2 \\
\hline Black plastic & 7.0 & 0.30 & 1.2 \\
\hline
\end{tabular}

\section{Nursery rising}

Chili seeds were broadcasted in the seed bed on 18th February and then bed was covered with polyethylene sheet to protect it from the frost and heavy rains. Seed bed was irrigated and weeding was done after removal of plastic sheet.

\section{Experimental design}

The experiment was carried out in Randomized Complete Block Design (RCBD) two factor having three replications with plot size $2 \times 2 \mathrm{~m}$. Row to row and plant to plant distances were kept 60 and $30 \mathrm{~cm}$ respectively.

Table 3. shows Factors

\begin{tabular}{|l|l|}
\hline Factor A: & Factor B: \\
\hline Mulching materials & Chili cultivars \\
\hline$M_{1}$ - Wheat straw & $\mathrm{C}_{1}$ - Pusa Jawala \\
\hline $\mathrm{M}_{2}$ - Saw dust & $\mathrm{C}_{2}$ - Sky Star \\
\hline $\mathrm{M}_{3}$ - Transparent plastic & $\mathrm{C}_{3}$ - Hot Green \\
\hline $\mathrm{M}_{4}$ - Black plastic & $\mathrm{C}_{4}$ - Green Star \\
\hline $\mathrm{M}_{5}$ - Unmulched & \\
\hline
\end{tabular}

\section{Fertilizer application}

Nitrogen, Phosphorus and Potash were applied at the rate of 100:50:50 $\mathrm{ha}^{-1}$. Nitrogen was applied in two split doses. Half dose of Nitrogen and full doses of Phosphorus and Potash were supplied before transplanting, while the remaining half dose of Nitrogen was applied after 30 days.

\section{Application of mulches}

Before transplanting of plant to the field mulches were applied. $5 \mathrm{~cm}$ thick layer of saw dust and wheat straw were spread on the rows having $.5 \mathrm{~cm}$ thickness $6 \mathrm{~cm}$ away from the plants. Plastic mulches were applied by covering the rows and for each plant a separate hole was made. The sides of plastic mulches were covered with soil in order to 
avoid removal of the applied materials by wind blow.

\section{Transplantation of seedlings}

Vigorous and diseased free seedlings with the same heights were transplanted from the nursery bed to the field on 16th April. Prior to the transplantation field was irrigated.

\section{Parameters studied}

Following parameters were studied during the experiment.

1. Soil moisture content $(\%)$

2. Weed density $\mathrm{m}^{-2}$

3. Days to flowering

4. First harvest time (days)

5. Plant height $(\mathrm{cm})$

6. Number of branches

7. Number of Fruits

8. Fruit length $(\mathrm{cm})$

9. Fruit weight $(\mathrm{g})$

10. Yield tons $\mathrm{ha}^{-1}$

\section{Statistical analysis}

Analysis of all parameters of the study was done with MSTAT-C. The LSD test was taken out at $5 \%$ probability [15].

\section{Results and discussion}

\section{Soil moisture content (\%)}

Data regarding soil moisture content $(\%)$ is shown in Table 4, Data shows that soil moisture content (\%) was significantly affected by mulching materials whereas cultivars and interaction were found nonsignificant. It is observed from the mean table that highest soil moisture content (22.5 $\%)$ was found under black plastic which was statistically similar to transparent plastic (22.3\%), while lowest soil moisture content $(16.1 \%)$ was observed in Unmulched plots. High moisture retention ability of plastic mulches could be due to less evaporation from soil. The water vapors that evaporate from the soil surface further trapped in the plastic and dropped again into the upper soil surface which increases soil moisture content in the root zone. These results are in agreement with [16] they stated that maximum moisture content was noted in plots mulched with transparent polyethylene mulch while minimum soil moisture content was noted in control plots. [10] reported that all mulch materials retained highest soil moisture content as compared to bare plots, especially transparent plastic mulch retained highest soil moisture which is followed by black plastic. Related results were also noted by [17] they stated that the beds which were mulched conserved more moisture content than unmulched plots, which result in increased plant growth.

Weed density $\left(\mathrm{m}^{-2}\right)$

Data concerning weed density is shown in Table 4, The data shows that mulching materials significantly affect the weed density while cultivars and interaction were found non-significant data shows that all mulching materials except transparent plastic mulch reduced weed density as compare to Unmulched plots. The highest numbers of weeds $\mathrm{m}^{-2}$ were found under transparent plastic mulch (209) while lowest were found under black plastic mulch (19). Maximum number of weeds were found under transparent plastic mulch which might be due to direct entrance of light and also due to higher soil moisture content as well as high soil temperature; on the other hand under black plastic mulch weeds were only found in the planting holes and cracks this might be due to blocking of solar radiation which result in the blocking of photosynthesis inside the plastic. Present conclusions are in agreement with [18] they observed that mulching materials result in reduction of weeds as compared to unmulched plots. Also [10] reported that highest numbers of weeds were found in transparent polyethylene mulch while lowest numbers of weeds were found under black plastic. Alike results were noted by [14] they observed that weeds were suppressed under black and silver/black mulch while clear, blue and red mulches encouraged weeds.

Days to flowering 
Data recorded on number of days to flowering is given in Table 4. Data shows that days to flowering in chili plant were affected significantly by mulching materials and chili cultivars, while interaction was found non-significant. Mean table shows that maximum days to flowering (40) were observed in Unmulched plots, while lowest days to flowering (36) were noted in transparent plastic mulch. In case of cultivars maximum days to flowering (41) were noted in cultivar Pusa Jawala, while minimum days to flowering were noted in Sky Star (36) and Hot Green (36). Genetic makeup and varietal characteristics shown difference in chili cultivars. [19] noted that differences were noted in days to flowering in different cultivars due to genetic makeup and environmental conditions.

The early in flowering with the use of polyethylene mulch may be due to increase in soil temperature which promote rapid growth and early maturity of plant. The current findings are in agreement with [20] they reported that early flowering in squash can be developed with the use of plastic mulch. Also [21] reported that early flowering were noted in clear plastic mulch followed by black plastic mulch while maximum days to flowering were noted from control plots. Similar results were noted by [5] they observed that minimum days to flowering were noted in polyethylene plastic then other mulch materials and control.

\section{First harvest time (days)}

Data showing first harvest time is presented in Table 4. Data shows that mulching materials and cultivars significantly affected first harvest time in chili while interaction was found non-significant. Maximum days to first harvest time (59) were noted in Unmulched plots while minimum days to first harvest time (49) took in transparent plastic. In case of cultivars maximum days to first harvest time (61) were observed in
Pusa Jawal, while lowest days were noted in Hot Green (51) and Green Star (51). Variation in first harvest time in cultivars might be due to environmental conditions, genetic makeup or varietal characteristics. [5] reported that variations in days to harvesting may be due to genetic makeup of the cultivars.

The reduction in days to first harvest time in plastic mulch might be due to increased soil temperature, high soil moisture content and reduction in nutrients leaching. All these reasons result in rapid growth and early fruit maturity. Present results supports the findings of [22] they observed that with the use of plastic mulch plants take less days to maturity, this is due to soil moisture conservation, uniform temperature and better root development which results in early fruit ripening. Also [21] stated that early flowering and fruiting in melon were noted on clear mulch than on black plastic mulch as compared to bare soil. Similar findings were noted by [5] they stated that minimum days to harvesting were noted in transparent plastic mulch followed by black plastic mulch, while maximum days to harvesting were observed in control.

\section{Plant height (cm)}

Data regarding plant height is given in Table 4. Analysis of variance reflected that various mulching materials and cultivars significantly affected plant height, while interaction was non-significant. In mulching materials maximum plant height $(106.4 \mathrm{~cm})$ was observed in transparent plastic, followed by black plastic $(101.8 \mathrm{~cm})$ while the minimum plant height $(81.6 \mathrm{~cm})$ was noted in Unmulched plots. In case of cultivars maximum plant height $(107.9 \mathrm{~cm})$ was noted in Hot Green while minimum plant height $(56.9 \mathrm{~cm})$ was observed in Sky Star.

Plant tallness is a role of many factors like influences of environmental interactions, soil condition and genetic makeup. [16] 
reported that the differences in plant height among different cultivars may be attributes by the variation in genetic makeup of the different cultivars and its adaptation ability to the environment. [21] reported that there were significant differences noted in melon cultivars in term of plant height.

Increase in plant height by polyethylene mulches might be due to increase in soil temperature, high soil moisture content and well developed root system. The above result is in agreement with [23] reported that with the use of polyethylene mulch height of okra got increased. Similar results were noted by [24] they reported that plant height was maximum under black plastic mulch as compare to other treatments which might be due to high soil temperature.

Table 4. Soil moisture content (\%), Weed density $\mathbf{m}^{-2}$, Days to flowering, First harvest time (days), Plant height (cm)

\begin{tabular}{|l|l|l|l|l|l|}
\hline & $\begin{array}{c}\text { Soil Moisture } \\
(\%)\end{array}$ & $\begin{array}{c}\text { Weed Density } \\
\mathbf{m}^{2}\end{array}$ & $\begin{array}{l}\text { Days to } \\
\text { Flowering }\end{array}$ & $\begin{array}{l}\text { First time } \\
\text { harvest }\end{array}$ & $\begin{array}{c}\text { Plant Height } \\
(\mathbf{c m})\end{array}$ \\
\hline $\begin{array}{l}\text { Mulching } \\
\text { Materials }\end{array}$ & & & & & \\
\hline Wheat dust & $19.2 \mathrm{~b}$ & $124 \mathrm{c}$ & $37 \mathrm{~b}$ & $52 \mathrm{bc}$ & $85.3 \mathrm{c}$ \\
\hline Saw dust & $19.4 \mathrm{~b}$ & $103 \mathrm{c}$ & $38 \mathrm{~b}$ & $55 \mathrm{ab}$ & $89.3 \mathrm{bc}$ \\
\hline $\begin{array}{l}\text { Transparent } \\
\text { Plastic }\end{array}$ & $22.3 \mathrm{a}$ & $209 \mathrm{a}$ & $36 \mathrm{c}$ & $49 \mathrm{c}$ & $106.4 \mathrm{a}$ \\
\hline Black Plastic & $22.5 \mathrm{a}$ & $19 \mathrm{~d}$ & $37 \mathrm{~b}$ & $54 \mathrm{~b}$ & $101.8 \mathrm{ab}$ \\
\hline Unmulched & $16.1 \mathrm{c}$ & $168 \mathrm{~b}$ & $40 \mathrm{a}$ & $59 \mathrm{a}$ & $81.6 \mathrm{c}$ \\
\hline LSD (0.05) & 0.809 & 64.862 & 1.431 & 4.299 & 13.01 \\
\hline Cultivars & & & & & \\
\hline Pusa Jawala & 20.3 & 127 & $41 \mathrm{a}$ & $61 \mathrm{a}$ & $101.3 \mathrm{a}$ \\
\hline Sky Star & 19.7 & 126 & $36 \mathrm{a}$ & $53 \mathrm{~b}$ & $56.9 \mathrm{~b}$ \\
\hline Hot Green & 19.8 & 122 & $36 \mathrm{~b}$ & $51 \mathrm{~b}$ & $107.9 \mathrm{a}$ \\
\hline Green Star & 19.7 & 123 & $37 \mathrm{~b}$ & $51 \mathrm{~b}$ & $105.5 \mathrm{a}$ \\
\hline LSD (0.05) & & & 1.280 & 3.845 & 11.637 \\
\hline
\end{tabular}

\section{Number of branches plant ${ }^{-1}$}

Data showing number of branches plant ${ }^{-1}$ is given in Table 5. Mean table shows that number of branches plant ${ }^{-1}$ was significantly affected by mulching materials and cultivars whereas interaction remained nonsignificant. In mulching materials maximum numbers of branches (8) were recorded where black plastic was used while minimum numbers of branches (3) were noted in Unmulched plots. Among cultivars maximum number of branches plant ${ }^{-1}$ (7) were produced by Sky Star while minimum number of branches plant ${ }^{-1}(4)$ were noted in cultivar Hot Green which was statistically similar to Pusa Jawala which also produced same number of branches (4).

Branching of a plant is one of the important aspects in fruit production; variation among cultivars in production of branches may be due to their genetic makeup. The above results are similar with the results of [25] they noted that cultivars have different genetic potential in the relation of their vegetative and reproductive components.

In case of mulching materials increase in growth parameters may be attributed by sufficient soil moisture near root zone which is trapped under mulching material. The extended retention of moisture also leads to higher uptake of nutrient for proper growth 
and development of plants. The currents findings are in agreement was [10] stated that mulching materials significantly affected structure branches of chili plants particularly black plastic mulch produce maximum number of branches followed by transparent and blue plastic. Similar results were noted by [14] they reported that mulching significantly increase number of branches in tomato plant as compared to bare soil.

\section{Number of fruits plant ${ }^{-1}$}

Data on number of fruits plant ${ }^{-1}$ is shown in Table 5. Mean data shows that number of fruits plant $^{-1}$ was significantly affected by mulching materials and cultivars while interaction was found non-significant. In mulching materials maximum numbers of fruits (112) were obtained when black plastic was used while minimum number of fruits plant ${ }^{-1}$ (36) were noted in Unmulched plots. In case of cultivars maximum number of fruits (133) were recorded at chili cultivar Sky Star while minimum number of fruits plant $^{-1}$ (32) were noted at cultivar Pusa Jawala. Cultivars effected number of fruits plant $^{-1}$ significantly which might be due to variation among varieties. [21] reported that there were significant differences among melon cultivars in term of number of fruits per plant. [27] reported that varietal variations in the yield components of watermelon show the potential and inherent superiority of cultivars for exploiting its production.

Mulching materials especially black plastic mulch fully control weeds by inhibiting photosynthesis inside the plastic, which reduce the competition with plants as a result plant get maximum nutrients from soil which results in higher number of fruits plant $^{-1}$. These results are similar with [26] they stated that watermelon produced 96.61\% more fruits per plant under dark mulch as compared to control plots. Also [28] reported that mulching materials significantly affected number of fruits per plant of tomato varieties. He stated that maximum number of fruits per plant were obtained from plots mulched with water hyacinth followed by straw mulch while, minimum fruits per plant were obtained from control plots. Similar effects were noted by [21] they observed that number of fruits plant $^{-1}$ in watermelon cultivars were significantly affected by mulching materials especially transparent plastic mulch produce maximum number of fruits plant $^{-1}$ as compared to other mulching materials. [29] observed that light and dark mulch produce maximum number of fruits as compared to control.

\section{Fruit length (cm)}

Data showing fruit length is given in Table 5. shows that fruit length was significantly affected by mulching materials cultivars, while interaction between cultivars and mulching materials remained nonsignificant. In mulching materials maximum fruit length $(13.3 \mathrm{~cm})$ was noted in transparent plastic mulch which was statistically similar to black plastic mulch $(13.2 \mathrm{~cm})$, whereas minimum fruit length $(11.3 \mathrm{~cm})$ was noted under Unmulched plots. In case of cultivars maximum fruit length $(13.4 \mathrm{~cm})$ was noted in cultivar Pusa Jawala, while minimum fruit length (10.9 $\mathrm{cm})$ was noted in cultivar Sky Star.

Chili fruit length is one of the important parameter which determines production capacity, plant nutrition and environmental condition greatly affect it. Genetic makeup is one of the reason for variation in fruit length among cultivars. The results are similar with the findings of [28] they observed that varietal variations in the yield component are due to genetic makeup of the cultivars.

Increase in fruit length when plastic mulches were used might be attributed by enhanced soil temperature and conserved soil moisture. The current results are similar 
with the findings [5] reported that maximum fruit length $(8.85 \mathrm{~cm})$ was found in black plastic mulch which was statistically similar to transparent plastic mulch followed by sugarcane begas. Similar results were also observed by [30] he reported that mulching have significant effect on fruit length of sweet pepper. He noted maximum fruit length from the plots mulched with black plastic while, minimum was noted in the plots mulched with grass. He stated that this might be due to varying soil moisture content conserved by different mulching materials. [31] reported that Maximum fruit length was noted in silver on black plastic mulch, while the minimum fruit length of watermelon was observed in control.

\section{Fruit weight (g)}

The data relating weight of fruit is presented in Table 5, shows that chili fruit weight was significantly affected by mulching materials and cultivars, while interaction was found non-significant. From the mean table it is observed that maximum fruit weight $(4.8 \mathrm{~g})$ was obtain from black plastic mulch, while minimum fruit weight $(3.5 \mathrm{~g})$ was recorded in Unmulched plots. In case of chili cultivars maximum fruit weight $(5.2 \mathrm{~g})$ was recorded in chili cultivar Hot Green which was statistically similar to Green Star $(5.0 \mathrm{~g})$, while minimum fruit weight was noted in cultivar Sky Star (2.6 g).

Fruit weight is one of the most important parameter in the yield component, due to which total yield may be increase or decrease. Variation among chili cultivars in fruit weight might be due to varietal characteristics, climatic conditions or genetic potential. The above results are similar with the findings of [25] they reported that cultivars are different in their genetic makeup in relation of growth and yield components. [29] reported difference in fruit weight of different tomato cultivars. In mulching materials high soil moisture content, accumulation of nutrients in the root zone of plant and particularly in black plastic mulch weeds are almost absent which leads to maximum fruit weight. The above results are similar to the results of [27] they reported that mulching materials significantly affected individual fruit weight of tomato varieties. They observed maximum individual fruit weight from the plots mulched with water hyacinth followed by straw while, minimum was noted from unmulched plots. Also [10] reported that maximum fruit weight was noted in black plastic mulch followed by transparent and blue plastic mulch as compared to control. Similar results were also observed [5] they stated that maximum fruit weight was noted in black plastic mulch followed by transparent plastic mulch while minimum fruit weight was reported in control plots. [31] stated that mulching materials significantly increased the average fruit weight in water melon when compared with unmulched plots.

\section{Yield tons ha-1}

Data on yield tons $\mathrm{ha}^{-1}$ is given in Table 5 . Mean tables show that yield tons $\mathrm{ha}^{-1}$ were affected significantly by mulching materials and cultivars, while interaction between cultivars and mulching materials was found non-significant. The maximum fruit yield (3.07 tons $\mathrm{ha}^{-1}$ ) was recorded in black plastic mulch while the minimum fruit yield $(0.70$ tons $\mathrm{ha}^{-1}$ ) was noted in Unmulched plots. In cultivars higher yield (2.33 tons ha ${ }^{-1}$ ) was obtain from chili cultivar Sky Star while the lowest yield (1.29 tons ha ${ }^{-1}$ ) was noted in cultivar Pusa Jawala.

Differences in yield tons $\mathrm{ha}^{-1}$ of chili cultivars might be due to varietal characteristics and its genetic makeup. Present results are similar with the findings of [32] who reported that higher dry chili yield produced by Byadagi kaddi may be due to its adaptability to local conditions and better habit than other cultivars. Plastic mulch reduces evaporation, reduces 
fertilizer leaching, reduces soil compaction, increase soil temperature and have very few weeds particularly in black plastic mulch. These properties leads to well-developed root system of plant, high soil moisture and nutrients retention within root zone which ultimately result in higher crop yield. These results are similar with the conclusion of [33] who reported that different mulching materials significantly increased vegetative and yield components of tomato. Also Mahmood et al. [17] reported that production of cucumber and bitter gourd were increased by $39.33 \%$ and $23.71 \%$ in mulched condition than non-mulch condition. Similar results were noted by [10] they observed that black plastic mulch produced high fruit weight plant $^{-1}$ and per hectare followed by blue and transparent plastic mulches than unmulched plots. [34] reported that mulches have significant effect on yield parameters of squash. They stated that black plastic mulched plots gave maximum yield as compared to unmulched plots, organic mulches also increased yield significantly than control.

Table 5. Number of branches, Number of Fruits, Fruit length $(\mathrm{cm})$, Fruit weight $(\mathrm{g})$, Yield tons ha-1

\begin{tabular}{|l|l|l|l|l|l|}
\hline & $\begin{array}{l}\text { Number of } \\
\text { branches }\end{array}$ & $\begin{array}{l}\text { Number of } \\
\text { Fruits }\end{array}$ & $\begin{array}{l}\text { Fruit length } \\
(\mathbf{c m})\end{array}$ & $\begin{array}{c}\text { Fruit weight } \\
(\mathbf{g})\end{array}$ & Yield tons ha' \\
\hline $\begin{array}{l}\text { Mulching } \\
\text { Materials }\end{array}$ & & & & & \\
\hline Wheat dust & $4 \mathrm{c}$ & $57 \mathrm{bc}$ & $12.0 \mathrm{c}$ & $4.0 \mathrm{c}$ & $1.50 \mathrm{c}$ \\
\hline Saw dust & $1.50 \mathrm{c}$ & $51 \mathrm{~cd}$ & $12.1 \mathrm{~b}$ & $4.2 \mathrm{bc}$ & $1.34 \mathrm{c}$ \\
\hline $\begin{array}{l}\text { Transparent } \\
\text { Plastic }\end{array}$ & $6 \mathrm{~b}$ & $75 \mathrm{~b}$ & $13.3 \mathrm{a}$ & $4.5 \mathrm{ab}$ & $2.05 \mathrm{~b}$ \\
\hline Black Plastic & $8 \mathrm{a}$ & $112 \mathrm{a}$ & $13.2 \mathrm{a}$ & $4.8 \mathrm{a}$ & $3.07 \mathrm{a}$ \\
\hline Unmulched & $3 \mathrm{~d}$ & $36 \mathrm{~d}$ & $11.1 \mathrm{c}$ & $3.5 \mathrm{~d}$ & $0.70 \mathrm{~d}$ \\
\hline LSD (0.05) & 0.984 & 18.560 & 0.559 & 0.422 & 0.449 \\
\hline Cultivars & & & & & \\
\hline Pusa Jawala & $4 \mathrm{c}$ & $32 \mathrm{c}$ & $13.4 \mathrm{a}$ & $4.0 \mathrm{~b}$ & $1.29 \mathrm{c}$ \\
\hline Sky Star & $7 \mathrm{a}$ & $133 \mathrm{a}$ & $10.9 \mathrm{c}$ & $2.6 \mathrm{c}$ & $2.33 \mathrm{a}$ \\
\hline Hot Green & $4 \mathrm{c}$ & $51 \mathrm{~b}$ & $12.5 \mathrm{~b}$ & $5.2 \mathrm{a}$ & $1.75 \mathrm{~b}$ \\
\hline Green Star & $5 \mathrm{~b}$ & $48 \mathrm{bc}$ & $12,6 \mathrm{~b}$ & $5.0 \mathrm{a}$ & $1.56 \mathrm{bc}$ \\
\hline LSD (0.05) & 0.880 & 16.600 & 0.500 & 0.377 & 0.401 \\
\hline
\end{tabular}

\section{Conclusions and recommendations}

From the data it is clear that mulching materials significantly affected all growth ad yield parameters of chili cultivars especially black plastic mulch showed best result in weed density $\mathrm{m}^{-2}$, number of branches plant ${ }^{1}$, number of fruits plant $^{-1}$, fruit weight, and yield tons $\mathrm{ha}^{-1}$. Transparent plastic showed best results in minimum days to flowering, first harvest time and maximum plant height. In case of soil moisture content and fruit length both black plastic and transparent plastic mulch showed similar results. Unmulched plots show poor results in all parameters of the study as compare to mulched plots. In cultivars Sky Star showed better performance in number of branches plant $^{-1}$, number of fruits plant ${ }^{-1}$, and yield tons $\mathrm{ha}^{-1}$.Minimum days to flowering and first harvest time were found in Sky Star, Hot Green and Green Star which were statistically similar. Maximum fruit length was noted in cultivar Pusa Jawala while maximum fruit weight was observed in Hot Green. It is recommended that black plastic mulch should be used for better production 
of chili. Among tested cultivars, Sky Star showed best results in growth and yield parameters and hence should be used along with black plastic mulch by the farmers of Peshawar Valley to achieve higher yield and better weed management.

\section{Authors' contributions}

Conceived and designed the experiments: MN Khan \& G Ayub, Performed the experiments: MN Khan, M Ilyas, M Khan \& J Ali, Analyzed the data: MN Khan \& FU Haq, Contributed reagents/ materials/ analysis tools: A Alam \& J Ali, Wrote the paper: MN Khan.

\section{References}

1. Naz S, Anjum MA \& Ahmad I (2006). Growth of chilli (Capsicum annum L.). F1 hubrid sky line-2 in response to different age of transplants. Research. (Sci). Bahauddin Zakariya Uni. Multan, Pakistan. 17 (2): 91-95.

2. Bhuvaneswari G, Sivaranjani S, Reeth \& Ramakrishnan K (2013). Application of Nitrogen and Potassium efficiency on the growth and yield of chili Capsicum annuum L. Inernational. Journal of Current Microbiology and Applied Science 2 (12): 329-337.

3. Bosland PW (1992). Chilies a diverse crop. Horticulture. Technology 2 (1): 7-10.

4. Govt. of Pakistan. 2008-09. Fruits, vegetables and condiments Statistics of Pakistan. Ministry of Food, Agric. \& Livestock. Federal Bureau of Statistics, Islamabad, Pakistan.

5. Ahmad I, Husain Z, Reza S, Memon N \& Naqvi SA (2011). Response of vegetative and reproductive components of chili to inorganic and organic mulches.

Pakistan Journal. Of Agriculture Science 48 (1):19-24.

6. Kumar SD \& Lal BR (2012). Effect of mulching on crop production under rainfed condition. International Journal of Research Chemistry and Enviroment 2 (2): 8-20.

7. Vos J \& Sumarni N (1997). Integrated crop management of hot pepper (Capsicum Spp.) under tropical lowland conditions:
Effect of mulch on crop performance and production. Horticultural Science 72: 415424.

8. Unger PW (1995). Role of mulch in dry land agriculture. In: U.S. Gupta (ed). Production and improvement of crops for dry lands. Oxford \& IBH Publishing, New Delhi.

9. Ayub k (1986). Effect of available soil moisture on the yield of chili (capsicum annum). Technology Sayur Sayuran 2: 5759.

10. Ashrafuzzaman M, Hakim MA, Ismail MR, Shahidullah SM \& Hossain MA (2011). Effect of plastic mulch on growth and yield chili (Capsicum annum). Brazil. Arch. Boilogy and Technology 54 (2): 321-330.

11. Tarara JM (2000). Microclimate modification with plastic mulch. Horticultural Science 35 (2): 169-180.

12. Ham M, Kluitenberg GJ \& Lamont WJ (1993). Optical properties of plastic mulches affect the field temperature regime 118: 188-193.

13. Isik D, Kaya E, Ngouajio M \& Mennan M (2009). Weed suppression in organic pepper (Capsicum annum L.) with winter cover crops. Crop Protection 28: 356-363.

14. Rajablariani RH, Hassan F \& Rafezi R (2012). Effect of colored plastic mulches on yield of tomato and weed biomass. International Journal Environment Devt 3 (6).

15. Steel RGD, Torrie JH \& Dickey DA (1997). Principles and Procedures of Statistics: Abiometrical approach 3rd edition. McGraw Hill Book. International New York. Pp 172-177.

16. Khan MH, Chatt $\mathrm{T} \&$ Hayat R (2005). Growth and yield response of Tomato (lycopersicon esclentum L.) to organic and inorganic mulches. Asian Journal of plant. Science 4 (2): 128-131.

17. Mahmood N, Anees M, Ahmad S \& Zakaullah (2011). Effect of mulching on Vegetables production in tunnel farming. Mycopath 9 (1): 21-24.

18. Solaiman HM, Kabir MH, Uddin FM \& Hasanuzzaman M (2008). Black plastic mulch on flower production and petal colaration of aster. Botnay 1 (1): 05-08. 
19. Hamid A, Baloch JUD \& khan N (2002). Performance of six cucumbers (Cucumis sativus L.) Genotypes in swat Pakistan. International Journal of Agriculture and Biology 4(4).

20. Tuli A \& Yesilsoy MS (1997). Effect of soil temperature on growth and yield of squash under different mulch applications in polyethylene tunnel and open-air. Turkish Journal of Agriculture and Forestry 21: 101-108.

21. Ekinci M \& Dursun H (2009). Effect of different mulch materials on plant growth some quality prameters and yield in melon (Cucumis melo L.) cultivars in high altitude environmental condition. Pakistan Journal of Botnay 41 (4): 1891-1901.

22. Saijapongese AY, Ota YCR \& Wu CL (1989). Some aspects of cultural management in tomatoesat AVRDC. In: T.D. Griggs (ed.), Tomato and Pepper Production in the Tropic. Proc. Int. Symp. Integ. Mnag. Pract. Asian vegetable research and development center. Shanhua. Tainan. Taiwan. P. 349-357.

23. Olabode OS, Ogunyemi S \& Adesina GO (2007). Response of okra (Abelmoschus esculentus L.).Moench) to weed control by mulching. Journal of Food and Agricultural Enviroment 5(3 \& 4): 324 326.

24. Sing N \& Ahmad Z (2008). Effect of mulching on potato production in high altitude cold arid zone of Ladakh. Potato Journal 35(3-4): 118-121.

25. Young J, Meyers KJ, Derhide JV \& Liu RH (2004). Varietal Difference in Phenolic content and antioxidant and anti proliferative Activ vitiutrs of onion. Journal of Agriculture and Food chemistry 52 (22): 6787-6793.

26. Kashi A, Hosseinzadeh S, Babalar M \& Lessani H (2004). Effect of black polythylene mulch and calcium nitrate application on growth, yield and blossom- end rot of water melon cv. Charleston Gray. Journal crop production and processing 7(4): 1-10.

27. Kayum MA, Asaduzzaman M \& Haque MZ (2008). Effects of indigenous Mulches on Growth and yield of Tomato. Journal of Agriculture and Rural Development 6 (1 \& 2): 1- 6 .

28. Nwokwu $G \&$ Anickwe L (2014). Impact of different mulching materials on the growth and yield of watermelon (Citrullus lanatus L.) in Abakaliki, South eastern Nigeria. Agricultural and Health care Journal of Biology 4 (23): 2224-3208.

29. Hassandokht MR, Mohsenifar M \& Peyvast GA (2012). Effect of dark and light mulches on quantitative and qualitative traits of three tomato cultivars. Plant Ecophysiology 2. 193-197.

30. Belel MD (2012). Effect of grassed and synthetic mulching materials on growth and yield of sweet peppers (Capsiccum annum L.) in Mubi, Nigeria. Journal of Agriculture \& Social Science 8(3): 97-99.

31. Parmar HN, Polara ND \& Vradiya RR (2013). Effect of mulching materials on Growth, yield and quality of water melon (Citrullus lanatus Thunb) cv. Kiran. Universal Journal of Agricultural Research 1(2): 30-37.

32. Shashidhara Gb (2003). Effect of dates of planting on yield of chili cultivars under rainfed conditions in Alfisols of Northern Transition zone of Karanataka. Karantaka. Journal Agriculture science 16 (4).

33. Olassantan FO (1985). Effect of intercropping, mulching and stalking on growth and yield of tomatoes. Experimental Agriculture 21: 135-144.

34. Bhatt L, Rana R, Uniyal SP \& Sing VP (2011). Effect of mulch materials on vegetative characters, yield and economics of summer squash (Cucurbita pepo) under rainfed mid -hill condition of Uttarakhand. Vegetable. Science 38(2): 165-168. 